Images in...

\title{
Umbilical bile staining in a patient with gall-bladder perforation
}

\author{
Emma Fisken, Siddek Isreb, Sean Woodcock \\ Department of General surgery, Northumbria Healthcare NHS Trust, North Shields, UK
}

Correspondence to Siddek Isreb, drisreb@yahoo.com

\section{DESCRIPTION}

An elderly patient with known chronic obstructive airways disease presented with right upper quadrant pain. It was initially thought he had right lower lobe pneumonia and was treated accordingly. Over the course of the next couple of days, his liver function became deranged and a subsequent abdominal ultrasound suggested a diagnosis of acute cholecystitis. He was referred to the on-call surgical team where inspection of the abdomen revealed an umbilical hernia with associated yellow staining of the skin (figure 1). The patient was not systemically jaundiced. Clinically, the patient had peritonitis. An emergency diagnostic laparoscopy revealed a perforated gangrenous gallbladder with biliary peritonitis. The surgical management involved a subtotal cholecystectomy as the biliary anatomy was unclear, washout and drained.

A bile-stained umbilicus was first reported in 1905 by Ransohoff ${ }^{1}$ in a patient with spontaneous common bile duct perforation. Johnston ${ }^{2}$ described the sign in a case of gallbladder perforation in 1930. Bile within the peritoneal cavity has tracked through the umbilical hernia defect and stained the skin above the hernia sac. As far as we are aware, this is the only available image of this sign in the medical literature.

Competing interests None.

Patient consent Not obtained.

\section{REFERENCES}

1. Cullen TS. Embryology, Anatomy, and Diseases of the Umbilicus together with Diseases of the Urachus. Philadelphia, PA: Saunders 1916.

2. Johnston LB. Acute hemorrhagic pancreatitis: a case presenting yellow discoloration at the umbilicus. JAMA 1930;95:1587-8.

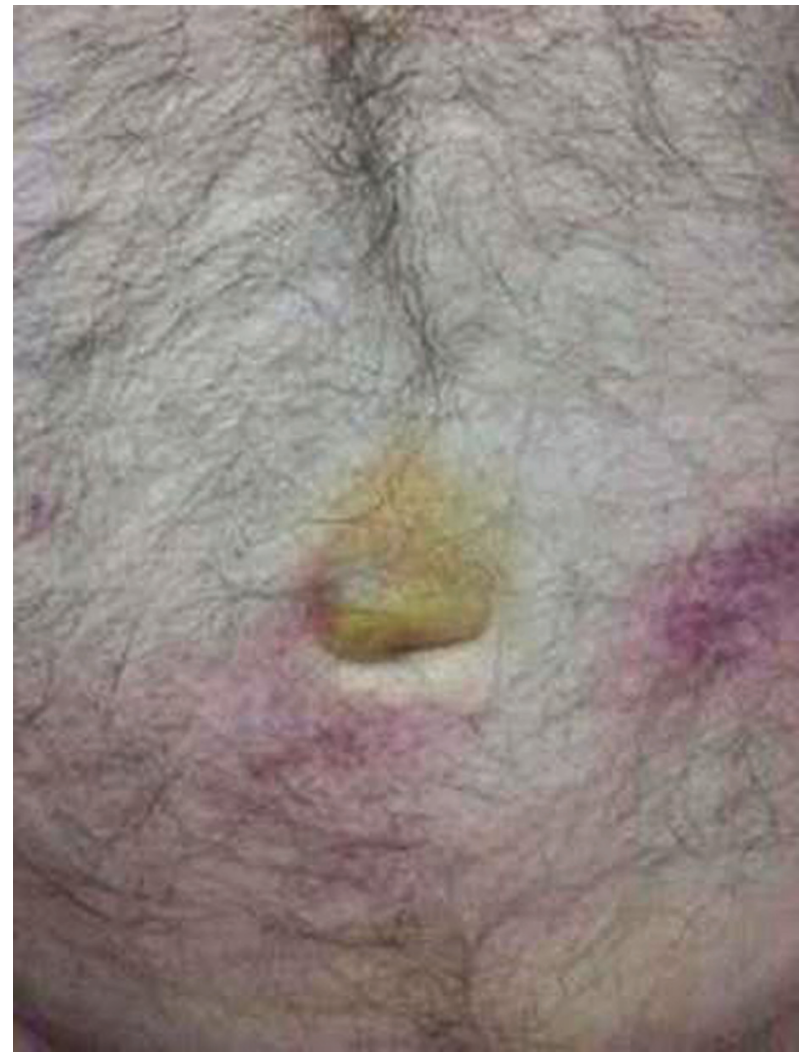

Figure 1 Incidental finding of umbilical bile - staining in a perforated gallbladder.

This pdf has been created automatically from the final edited text and images.

Copyright 2011 BMJ Publishing Group. All rights reserved. For permission to reuse any of this content visit http://group.bmj.com/group/rights-licensing/permissions.

BMJ Case Report Fellows may re-use this article for personal use and teaching without any further permission.

Please cite this article as follows (you will need to access the article online to obtain the date of publication).

Fisken E, Isreb S, Woodcock S. Umbilical bile staining in a patient with gall-bladder perforation. BMJ Case Reports 2011;10.1136/bcr.03.2011.4039, date of publication

Become a Fellow of BMJ Case Reports today and you can

- Submit as many cases as you like

- Enjoy fast sympathetic peer review and rapid publication of accepted articles

- Access all the published articles

- Re-use any of the published material for personal use and teaching without further permission

For information on Institutional Fellowships contact consortiasales@bmjgroup.com

Visit casereports.bmj.com for more articles like this and to become a Fellow 